\title{
A kulturális evolúció nyomai az örvös légykapó (Ficedula albicollis) énekében
}

\author{
VASKUTI ÉVA $^{1 *}{ }^{*}$ ZSEBŐK SÁNDOR $^{1}$, HERCZEG GÁBOR $^{1}$, BLÁZI GYÖRGY $^{1}$, \\ LACZI MIKLÓs ${ }^{1}$, NAGY GERGELY ${ }^{1}$, TÖRÖK JÁNOS ${ }^{1}$ és GARAMSZEGI LÁSZLÓ ZSOLT ${ }^{2}$ \\ ${ }^{1}$ Viselkedésökológiai Csoport, Eötvös Loránd Tudományegyetem, Állatrendszertani és Ökológiai Tanszék, \\ 1117 Budapest, Pázmány Péter sétány 1/C，*E-mail: vaskuti.eva@ gmail.com \\ ${ }^{2}$ Estación Biológica de Doñana-CSIC, c/ Américo Vespucio s/n, 41092 Sevilla, Spanyolország
}

\begin{abstract}
Összefoglalás. A kulturális evolúció folyamata - mely nem genetikai úton öröklött, hanem szociális tanulás útján, egyedek vagy generációk között történő információáramláson alapul - az emberré válás egyik fő mozgatórugója. Ez a kulturális evolúció azonban nemcsak az emberre jellemző sajátosság, hanem az állatok esetében is nagy jelentőséggel bír. A kulturális evolúció egyik alapfeltétele, hogy az egyedek viselkedési elemeket másolnak egymásról. Amikor ilyen másolásra kerül sor az éneklő madarak között, akkor az énekelemek, vagyis a szillablák használatának eloszlása térben és időben nem véletlenszerü, hanem strukturált lesz. Ennek a hipotézisnek a tesztelésére az örvös légykapó (Ficedula albicollis) egy pilisi populációjában 103 hím egyed 2005 és 2010 között rögzített 1740 énekét elemeztük. Populációs szinten 476 szillablafajtát definiáltunk. Az egyedek szillablahasználatában megmutatkozó átfedések feltárására hasonlósági mátrixokat számoltunk ki, és ezek között Mantel-teszttel vizsgáltuk, hogy a hímek énekének hasonlósága mutat-e térbeli és időbeli mintázatokat. A populáció énekösszetételében időbeli strukturáltságot írtunk le: az időben egymáshoz közelebb éneklő hímek éneke jobban hasonlít egymáshoz, mint az időben egymástól távolabb éneklő hímeké. Ezek az időbeli mintázatok léptékfüggőek voltak.A térbeli mintázat megléte nem volt statisztikailag igazolható. Ennek hiánya indokolható a rendelkezésre álló adatok alacsony számával, illetve, hogy kis geográfiai távolságokon esetleg nem kimutatható a térbeli mintázat. Összefoglalva tehát vizsgálatunkkal részben igazoltuk a kulturális evolúció meglétét az örvös légykapónál.
\end{abstract}

Kulcsszavak: szociális tanulás, szillabla, térbeli és időbeli mintázatok, Mantel-teszt, dendrogram.

\section{Bevezetés}

Amikor kultúráról beszélünk, akkor azt elsősorban az emberi társadalommal hozzuk összefüggésbe. Az emberek körében a szociális úton történő tanulás, az egyének közötti információátadás a társadalom müködésének egyik alappillére. Evolúciós szempontból, a kulturális folyamatok értelmezhetőek a tanult viselkedések generációk közötti változásaként (LUTHER \& BAPTISTA 2010). Számos tanulmány bizonyítja, hogy az ember mellett egyes állatfajoknál is fontos szerephez jut a szociális úton történő tanulás és a kulturális evolúció (BAKER et al. 2003, VAN SCHAIK 2010). Egyes egyedeknek más egyedek viselkedése szolgál mintául túlélésük illetve szaporodási sikerük növelésének szempontjából fon- 
tos döntéseik meghozatalában (GALEF \& LALAND 2005, DANCHIN \& WAGNER 2010). Például a fiatalabb egyedek megfigyelik, hogy a tapasztaltabb, idősebb fajtársaknak mi szolgálhat táplálékul, azt hogyan szerzik meg, használnak-e ehhez valamilyen eszközt, továbbá, hogy milyen predátorokat kerülnek el, vagy éppen azt, hogy miként választanak párt (GALEF \& LALAND 2005).

Az énekesmadarak énekét tanulmányozó kutatók egyetértenek abban, hogy az éneknek van egy tanult és egy öröklött része (CATCHPOLE \& SLATER 2008). Az ének tanulásának módja és mennyisége fajonként változhat, és ahol jelentős a tanulás aránya, ott számolni lehet a kulturális evolúció jelenségével (BEECHER \& BRENOWITZ 2005, CATCHPOLE \& SLATER 2008). A kulturális evolúció nyomait a madarak énekében többnyire olyan, egyszerübb énekü fajokon vizsgálták, mint például a koronás verébsármány (Zonotrichia leucophrys) (MARLER \& TAMURA 1964, BAPTISTA 1977, HARBISON et al. 1999, NELSON 2000). Az énekesmadarak többségének azonban ezeknél a modellfajoknál lényegesen bonyolultabb az éneke (CATCHPOLE \& SLATER 2008).

Az eddigi, énekesmadarakon végzett vizsgálatokban, föleg a térbeli elterjedés alapján értelmezhető dialektus jelenségét tanulmányozták (BAPTISTA 1977, PODOS et al. 2004, PODOS \& WARREN 2007, LAHTI et al. 2011). Dialektusról abban az esetben beszélhetünk, ha két szomszédos populáció repertoár készlete eltér egymástól, és ez az eltérés számottevőbb, mint az egyes populáción belül az egyedek közötti különbségek (LEMON 1975, MARLER \& TAMURA 1959). Ez a jelenség hasonlítható az emberi nyelvekben megjelenő nyelvjárásokhoz. Az egyedek egymástól való tanulása hozzájárul egy adott dialektus fennmaradásához (MARLER \& TAMURA 1959).

A madárének azonban nemcsak térben, hanem időben is mutathat mintázatokat (SLATER 1986, PODOS \& WARREN 2007, THIELTGES et al. 2014). Az időbeli mintázatok esetében az emberi divathullámokkal vonhatunk párhuzamot. Bizonyos elemek, vagy azok bonyolultabb kombinációi megjelenhetnek, majd gyorsan (néhány generáció múlva) el is tủnhetnek, mások akár több generáción keresztül is fennmaradhatnak (PODOS \& WARREN 2007). Az ének változásának van egy időbeli dimenziója is, ami jóval kevésbé ismert, mint a térbeli mintázat.

Az örvös légykapó (Ficedula albicollis) éneke ideális tárgya lehet kulturális evolúciós vizsgálatoknak, mert igen komplex: az egyedek egyenként 15-90 egyedi szillabla típust használnak sajátos kombinációban és két egyed repertoárja közötti hasonlóság kevesebb, mint 30\%, vagyis az ének nagymértékben egyedspecifikus (GARAMSZEGI et al. 2012). Egy egyed repertoárméretét az általa bemutatott különböző szillablatípusok száma határozza meg. Különböző énekbélyegek, mint például az énekhossz vagy a repertoárméret összefüggést mutatnak a korral, az egyedi minőséggel és a szaporodási sikerrel (GARAMSZEGI 2004, GARAMSZEGI et al. 2006, 2007). Ennek alapján valószínü, hogy az ének kiemelten fontos szerepet tölt be az örvös légykapók kommunikációjában, de nem tudjuk, hogy magának a komplexitásnak vagy az egyes szillablafajták sorrendje által definiált tartalomnak van-e funkciója, illetve azt sem, hogy ezek hogyan vesznek részt a kulturális evolúcióban.

Vizsgálatunkkal arra kerestünk választ, hogy az örvös légykapó változatos énekének kialakításában és fenntartásában szerepet játszik-e a kulturális evolúció. Irodalmi adatok alapján feltételeztük, hogy az örvös légykapó hímek másolnak egymásról bizonyos énekelemeket. Egyrészt a viszonylag nagy repertoárú madarak tipikusan tanulják az ének elemeket, 
(CATCHPOLE \& SLATER 2008), másrészt bizonyított, hogy az örvös légykapóval nagyon közeli rokon kormos légykapó (Ficedula hypoleuca) - mellyel az örvös légykapó hibridizálhat is, illetve a két faj hímjei feltételezhetően egymástól is átvesznek énekelemeket - tanulja az énekét (ERIKSEN et al. 2011). Ha ez valóban igaz, akkor a térben és/vagy időben egymáshoz közel éneklő hímek éneke jobban fog hasonlítani, mint az egymástól távol éneklő hímeké, és a hasonlóság alapján mintázatok rajzolódhatnak ki, ami a kulturális evolúció bizonyítéka lehet.

\section{Anyag és módszer}

\section{Hangfelvétel és hangfeldolgozás}

Az örvös légykapó kistermetű (12-13 g), hosszú távú vonuló énekesmadár. Áprilistól kora őszig Közép- és Kelet-Európában is előforduló faj, a teleket Afrikában tölti. Tavasszal, az érkezésüket követően a hímek területet foglalnak, majd intenzív éneklésbe kezdenek, melyet párba állásig folytatnak (GELTER 1987, WALLIN 1987, HEGYI et al. 2010). A vizsgálatban felhasznált énekek felvétele 2005 és 2010 között történt a Pilisszentlászló közelében fekvő kutatási területen, mely egy keleti és egy nyugati szektorra osztható $\left(47^{\circ} 43^{\prime} \mathrm{N}\right.$ $\left.19^{\circ} 01^{\prime} \mathrm{E}\right)$ (1. ábra).

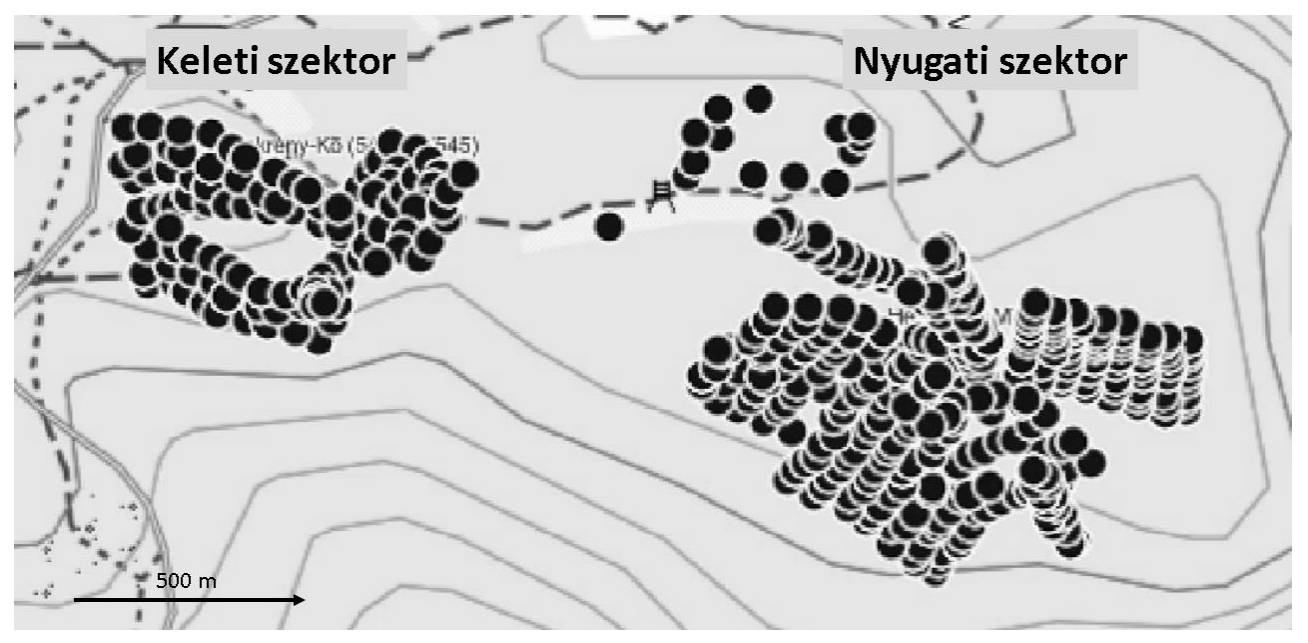

1. ábra. A kutatási terület: a fekete pontok a kihelyezett odúk GPS készülékkel kimért helyeit mutatják, továbbá jelölve van a kutatásban résztvevő két szektor.

Figure 1. Field site: black points indicate the GPS measured locations of each nest, the two areas of our investigations are also shown.

A vizsgált hat év alatt összesen 103 hím egyed énekét rögzítettük. Az énekeket a madártól kb. 20 méterre, elrejtőzve vettük fel, a felvevőt folyamatosan a madár felé irányítva. A felvétel előtt egy kalitkába zárt élö tojót helyeztünk ki 5 percre az odú tetejére, ezzel ösztö- 
nözve a hímet éneklésre, és standardizálva a felvétel körülményeit. A felvételek általában 6 és 13 óra között készültek Telinga parabola tányérral, melyhez Sennheiser ME62 mikrofon és K6 előerősítő csatlakozott. A hangrögzítés Tascam DR1 vagy Microtrack II kézi digitális felvevővel történt (mintavételezési frekvencia: $48 \mathrm{kHz}$, minőség: $16 \mathrm{bit}$ ). A hangfelvételt készítő személy a felvételre történő rámondással jelezte, ha a felvételen esetleg éppen nem a megfigyelt hím hangja volt hallható, illetve minden egyéb zavaró hatást, mint például másik hím vagy tojó megjelenését, hogy ezeket a későbbi feldolgozás során ki tudjuk szürni. Elöre felállított kritériumaink szerint a felvételnek legalább 10 perc hosszúnak kellett lennie, illetve tartalmaznia kellett minimum 20 jó minőségü éneket. Korábbi kutatásaink során ugyanis arra a megállapításra jutottunk, hogy az örvös légykapó esetében 20 ének jól reprezentálja a repertoárméretet (GARAMSZEGI et al. 2012).

A felvételekből az Adobe Audition 3.0 (Adobe Systems Incorporated) program segítségével vágtuk ki a feldolgozásra szánt énekeket. A kivágás során azokat a szillablaszekvenciákat tekintettük éneknek, melyek legalább három szillablából álltak (GARAMSZEGI 2002, GARAMSZEGI et al. 2007, 2012). Az énekek általában jól elkülöníthetőek egymástól, ha mégsem, akkor az átlagos szillablatávolságokból dönthető el, hogy valójában egy vagy két énekről van-e szó, mivel két egymást követő ének utolsó és első szillablája között nagyobb a távolság, mint az egyes énekeken belüli átlagos szillablatávolság. Ezt követően az énekekből szegmentáltuk a szillablákat, minden egyes szillablánál jelölve a hang elejét és végét, illetve annak alsó és felső frekvenciahatárait.

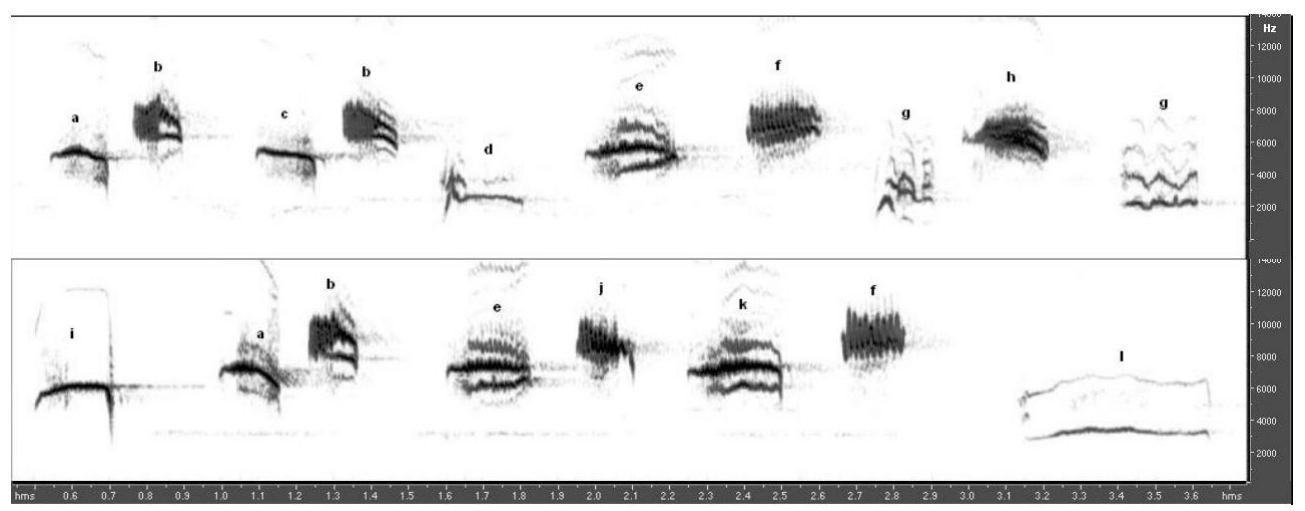

2. ábra. Két hím énekének szonogramja, amelyen betükkel jelöltük az egyes szillablafajtákat.

Figure 2. Sonograms of two males' song, each syllable type is marked by a different letter code.

Először az egyes hímek szillablái kerültek csoportosításra. Így határoztuk meg az adott egyed által használt szillablatípusokat (GARAMSZEGI et al. 2012). A csoportosítást egy MATLAB környezetben futó, saját fejlesztésű (ZSEBÖK S.) program segítségével végeztük. Ezt követően a kapott szillablacsoportokat egyed feletti szillablaosztályokba vontuk össze, a csoportosítás során használt program analógiájára készült, szintén MATLAB környezetben futó program segítségével (ZSEBÖK S.). A 103 hím hangjának felvételén összesen 15310 szillablát azonosítottunk. Az egyeden belüli csoportosítás folyamán 2450 szillablacsoport jött létre, amelyeket végül 476 egyed feletti szillablaosztályba soroltunk be. 
Azért, hogy a módszer objektivitását megvizsgáljuk, mind az egyed szerinti, mind pedig az egyed feletti csoportosítás esetében kappa statisztikával mértük a csoportosító személyek közötti egyezést abban a tekintetben, hogy az egyedi szilablákat hogyan csoportosítják (COHEN 1960). Az egyed szerinti csoportosítás során $\kappa=0,87$-et ( 25 , két különböző személy által párhuzamosan feldolgozott mintán tesztelve), míg az egyed feletti csoportosítás esetében $\kappa=0,83$-at (5, két különböző személy által párhuzamosan feldolgozott mintán tesztelve) kaptunk, abban az esetben, ha az egy szillablát tartalmazó csoportokat, illetve az egy szillabla csoportot tartalmazó szillabla osztályokat (azaz az egyed szerinti csoportosítás esetében az olyan szillabla csoportokat, amelyek a kivágást és csoportosítást követően mindössze egy szillablát, az egyed feletti csoportosítás esetében pedig azokat a szillabla osztályokat, amelyek mindössze egy szillabla csoportot tartalmaztak) nem vettük bele a mintába. Ez az eredmény azt mutatja, hogy a csoportosítást végző személyek osztályozási eredményei között nagy átfedés van (azaz ugyanazt a szillablát két ember nagy valószínüséggel ugyanabba a szillablaosztályba sorolja be), így a szubjektivitásból fakadó hiba minimálisnak tekinthetö (LANDIS \& KOCH 1977).

A kiegyensúlyozott mintavétel érdekében kivettük a vizsgálatból azokat a hímeket, amelyeknek kevesebb, mint 20 énekük volt, így az eredeti 103-ból 92 felvétel maradt. Négy egyed esetében két különböző évben is rögzítettünk hangot, így az egyik, random módon kiválasztott felvételt szintén kivettük a vizsgálatból. Egy hím esetében nem volt ismert a felvétel helye, így azt is kizártuk. Tehát az így korrigált adatbázison, 87, különböző évekböl származó hím egyeden, azaz független mintán végeztük a továbbiakban bemutatott vizsgálatainkat.

\section{Statisztikai módszerek}

Mivel minden évben vettünk fel énekeket a keleti és a nyugati szektorban is, így célirányos utólagos mintavételezést végeztünk, hogy a tér- és időhatást statisztikailag elválasszuk egymástól. Ezt úgy értük el, hogy az időhatást területre kontrollálva vizsgáltuk, azaz több különböző évben egy adott területre fókuszáltunk. A rendelkezésre álló adatszerkezet alapján az időhatást két független mintán tudtuk vizsgálni. Az első esetben, a nyugati szektorban udvarló légykapó hímek 2005-ös, 2006-os és 2009-es években felvett hangjait vizsgáltuk (1. táblázat). A második esetben, a keleti szektorban udvarló hímek 2007-es és 2008-as évekből származó énekét vizsgáltuk (1. táblázat). Hogy a két független mintavétel során kapott eredményeket azonos skálán is összevethessük, a nyugati szektorban felvett adatok két évre szükített (2005 és 2006) adatbázisán is végeztünk elemzéseket. A térfüggés vizsgálatát az időre kontrollálva úgy végeztük, hogy egy adott évböl, 2007-böl az odútelep különböző szektorából származó énekeket vizsgáltunk (1. táblázat).

A mintázatok vizualizálása érdekében az egyedek repertoáátfedésén alapuló hierarchikus osztályozást végeztünk klaszteranalízissel, összevonáson alapuló csoportátlag eljárással (UPGMA) (PODANI 1997). A módszer lényege, hogy első lépésként minden egyes hímhez hozzárendeljük egyesével az összes többi hímet, így párosával megbecsüljük a hímek szillablakészletén alapuló hasonlóságát a következő képlet segítségével (GARAMSZEGI et al. 2012):

$\mathrm{s}=1-0,5 * \sum\left|\mathrm{o}_{\mathrm{ik}} \mathrm{O}_{\mathrm{jk}}\right|$, ahol

$\mathrm{O}_{\mathrm{ik}}$, a $k$ szillabla előfordulásának relatív gyakorisága $i$ egyednél 
$\mathrm{O}_{\mathrm{jk}}$, a $k$ szillabla előfordulásának relatív gyakorisága $j$ egyednél.

A $k$ típusú szillabla relatív gyakoriságát úgy kapjuk meg egy adott hím énekében, hogy leszámoljuk a $k$ szillablák számát, és elosztjuk az ugyanebben a mintában előforduló összes szillabla számával. Ez az eljárás figyelembe veszi azt is, hogy egy adott szillablát milyen gyakorisággal használ egy adott egyed. Az átfedés mértéke 0 és 1 között mozog: 0 , ha egyáltalán nincs közösen használt szillabla, és 1, ha teljes az átfedés. Mivel a klaszteranalízis az egymástól való távolságon alapszik, a hasonlósági formula átalakításával távolságmátrixot hoztunk létre $\left(0,5^{*} \sum\left|\mathrm{o}_{\mathrm{ik}}-\mathrm{O}_{\mathrm{jk}}\right|\right)$. Ezt a távolságmátrixot vittük be végül a klaszteranalízisbe, mely egy dendrogram formájában jeleníti meg a hierarchikus osztályozás eredményét. Ezt a dendrogramot használtuk vizuális interpretációkban.

1. táblázat. Az egyes szektorokban, adott években felvett énekek száma és a vizsgálatokhoz kiválasztott minták. Világos szürkével jelölve az első időmodell mintái, vagyis a nyugati szektorban 2005 ben, 2006-ban és 2009-ben éneklő hímek. Sötétebb szürke színezéssel vannak jelölve a második időmodell vizsgálat mintái, ahol a keleti szektorban 2007-ben és 2008-ban éneklő hímeket vettük figyelembe. Továbbá keretezéssel van jelölve a térmodell vizsgálatunk mintavétele, ahol a 2007-ben mindkét szektor éneklő hímjeit vettük figyelembe.

Table 1. Recorded songs in different years and areas of the study. The samples that are chosen for differen comparisons (i.e. temporal and spatial models) are indicated by different colors: Light grey - first temporal model 2005, 2006 and 2009 western area; dark grey - second temporal model: 2007, 2008 eastern area; framed - spatial model: 2007 both areas.

\begin{tabular}{|c|c|c|}
\hline év/hely & nyugati szektor & keleti szektor \\
\hline $\mathbf{2 0 0 5}$ & 10 & 0 \\
\hline $\mathbf{2 0 0 6}$ & 18 & 0 \\
\hline $\mathbf{2 0 0 7}$ & 4 & 13 \\
\hline $\mathbf{2 0 0 8}$ & 1 & 10 \\
\hline $\mathbf{2 0 0 9}$ & 28 & 1 \\
\hline $\mathbf{2 0 1 0}$ & 0 & 2 \\
\hline
\end{tabular}

A távolságmátrixokat felhasználva, Mantel-teszttel vizsgáltuk (MANTEL 1967), hogy a repertoárátfedésen alapuló énekhasonlóság hogyan korrelál statisztikailag a hímek idő-, illetve térbeli elhelyezkedésével. Az időbeli elhelyezkedést leíró mátrix az énekek felvétele között eltelt évek számaiból állt. Tehát például egy 2006-os és egy 2009-es felvétel esetében három, míg az azonos években felvett egyedpárok esetében nulla. A területhatás vizsgálatánál jelen esetben csak azt néztük, hogy két adott hím ugyanazon vagy különbözö telepen énekelt-e. Az összehasonlítás eredményeként Pearson-féle r korrelációs együtthatót kaptunk, amely a két távolságmátrix kapcsolatának szorosságát és irányultságát mutatja meg. A Mantel-teszt randomizációs vizsgálattal adja meg a szignifikanciát, melynek során az adatokat randomizálja és elemzi, hogy a randomizálással kapott távolságmátrixok között milyen valószínűséggel kap meg a valós adatokon számolt (vagy annál nagyobb) r értékeket. A statisztikák és dendrogramok R programmal készültek (R CORE TEAM 2015, OKSANEN et al. 2016, PARADIS et al. 2004, SARKAR 2008, SCHLIEO 2011, SiMPSON 2016) 
A független szignifikanciatesztek együttes valószínűségének eljárásával (SOKAL \& ROHLF 1995) kombináltuk a $p$ értékeket abban az esetben, ha két független mintán teszteltük ugyanazt a hipotézist.

Teszteltük, hogy az egyes években vizsgált hímek kor szerinti megoszlásában volt-e különbség, ami szintén időbeli mintázatot eredményezhet tanulási mechanizmusoktól függetlenül. Ha a fiatal és idősebb egyedek éneke különbözik, valamint a populaciók koreloszlása térben és/vagy időben szintén különbözik, akkor az esetlegesen detektált repertoárbeli mintázatok nem feltétlenül tekinthetőek a kulturális evolúció eredményének. Az első időmodellünk esetében $\chi^{2}$ teszttel ellenőriztük, hogy a koreloszlás szignifikánsan különbözö-e a vizsgált évek között. A második időmodell esetében a mintánk kis elemszáma miatt Fisherféle egzakt próbával ellenőriztük ugyanezt.

\section{Eredmények}

\section{Idömodellek}

Az első esetben a 2005-ös, 2006-os és 2009-es évek éneklő hímjeit vizsgáltuk a nyugati szektorban. A dendrogram alapján a 2009-es évek hímjei bizonyos fokú, bár nem teljes elkülönülést mutatnak a 2005-ös és a 2006-os évek hímjeitől (3. ábra).

Sokkal kisebb mértékben, de azért megfigyelhető csoportokat alkotnak a 2005-ös és 2006-os évek hímjei is. Mantel-teszttel szignifikáns pozitív korrelációt találtunk a hímek énekének hasonlósága és időbeli elhelyezkedése között a nyugati szektor 2005-ös, 2006-os és 2009-es hímjei esetében ( $\mathrm{r}=0,21, \mathrm{p}<0,001)$ (4. ábra).

Mivel az előző vizsgálat dendrogramján feltünő volt a 2005-ben és 2006-ban rögzített énekek elkülönülése a 2009-ben felvettekétöl, ezért a második esetben megvizsgáltuk, hogy statisztikailag kimutatható-e különbség a 2005-ös és 2006-os évekből a nyugati szektorban rögzített énekek között. Nem volt kimutatható szignifikáns kapcsolat (Mantel-teszt: r=0,03, $\mathrm{p}=0,30)$.

Harmadik vizsgálatunkban ismét egy olyan esetet néztünk meg, ahol a minták két egymást követő évböl, 2007-ből és 2008-ból a keleti szektorból származtak (5. ábra). A különböző évekből származó felvételek szignifikáns eltérést mutattak (Mantel-teszt: r=0,262, p<0,001) (6. ábra). A független szignifikanciatesztek együttes valószínüsége alapján a két független mintán (nyugati szektor: 2005, 2006, 2009, keleti szektor: 2007, 2008) végzett időmodell összevont szignifikanciája erős eltérést mutatott a véletlen valószínüségtől $\left(\chi^{2}=35,455, \mathrm{df}=4, \mathrm{p}<0,0001\right)$. Így azt a következtetést tudtuk levonni, hogy az időhatás hosszabb időskálán tetten érhető, de az egymást követő években, illetve kis mintákra alapozva nem minden esetben lehet statisztikailag igazolni. 
VASKUTI É. et al.

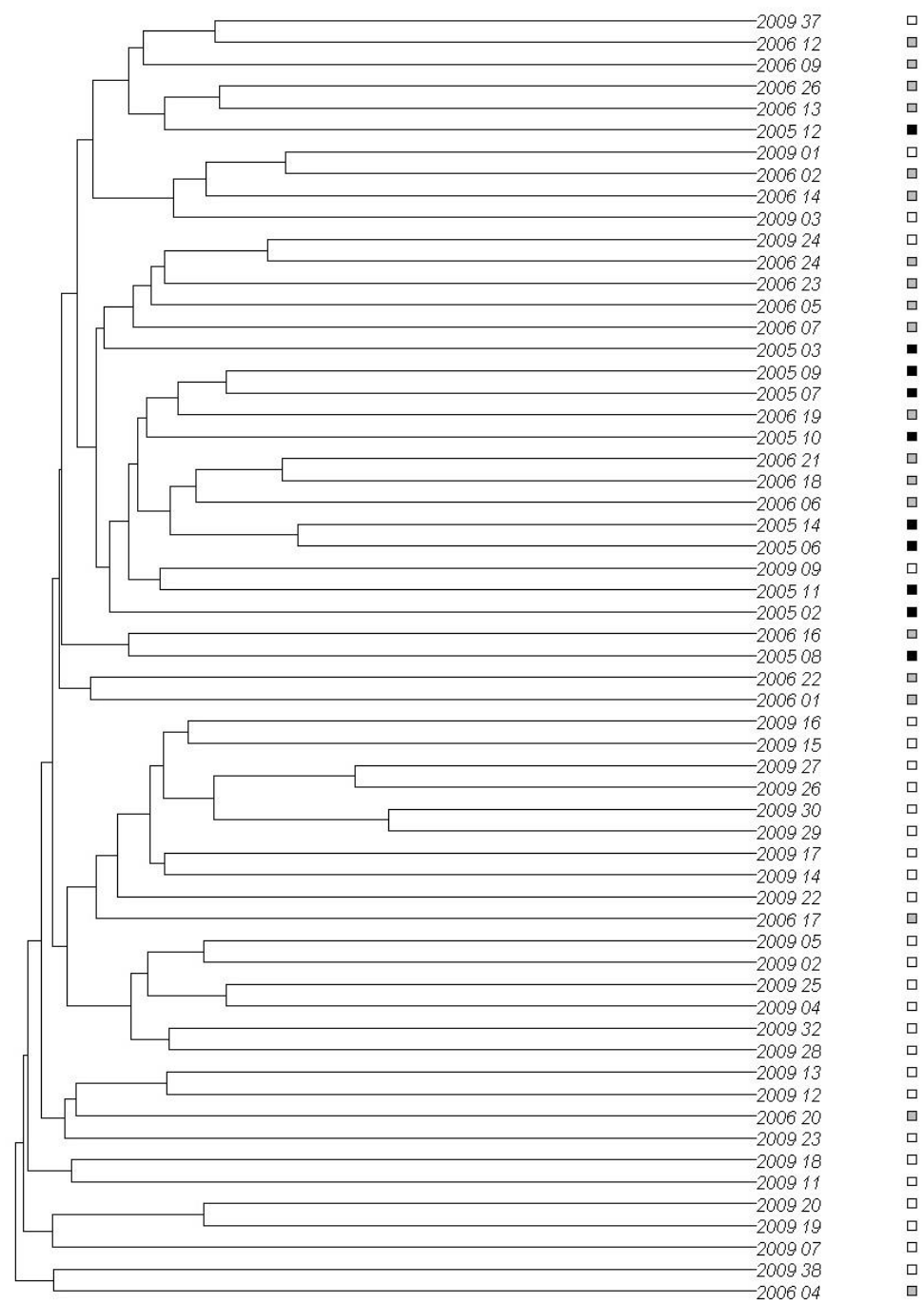

3. ábra. Az első időmodell dendrogramja (a nyugati szektorban 2005-ben, 2006-ban és 2009-ben éneklő hímek).

Figure 3. Dendrogram of the first temporal model (singing males in 2005, 2006 and 2009 in the western area of the field site). 


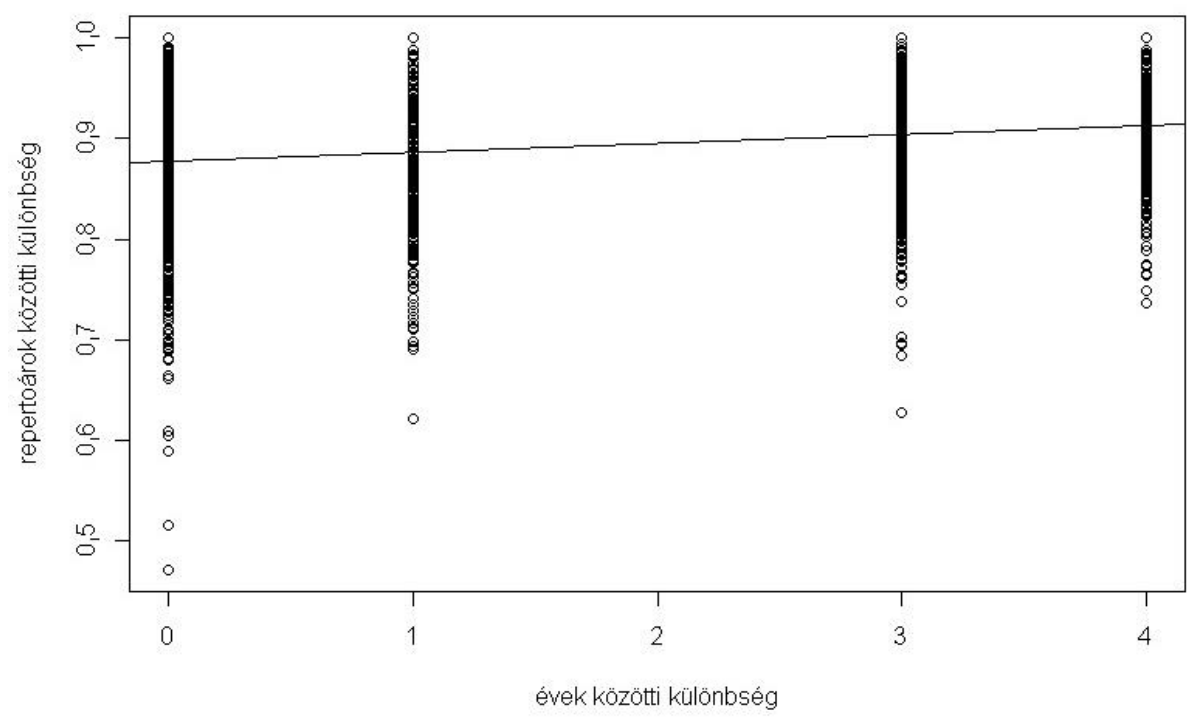

4. ábra. Diagramon ábrázolva a nyugati szektor 2005-ben, 2006-ban és 2009-ben éneklő hímjei.

Figure 4. Biplot of the singing males of 2005, 2006 and 2009 in the western area.

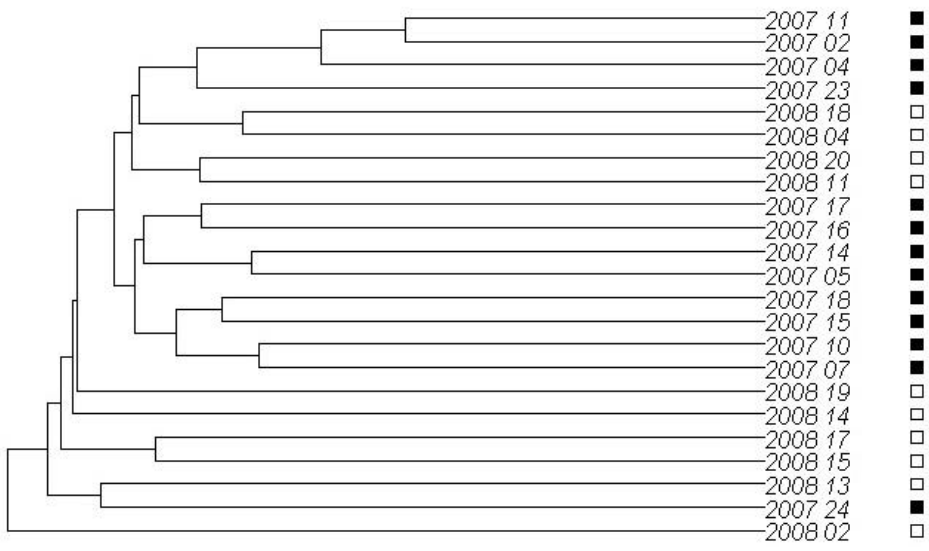

5. ábra. A második időmodell dendrogramja (a keleti szektorban 2007-ben és 2008-ban éneklö hímek).

Figure 5. Dendrogram of the second temporal model (singing males of 2007 and 2008 in the eastern area). 


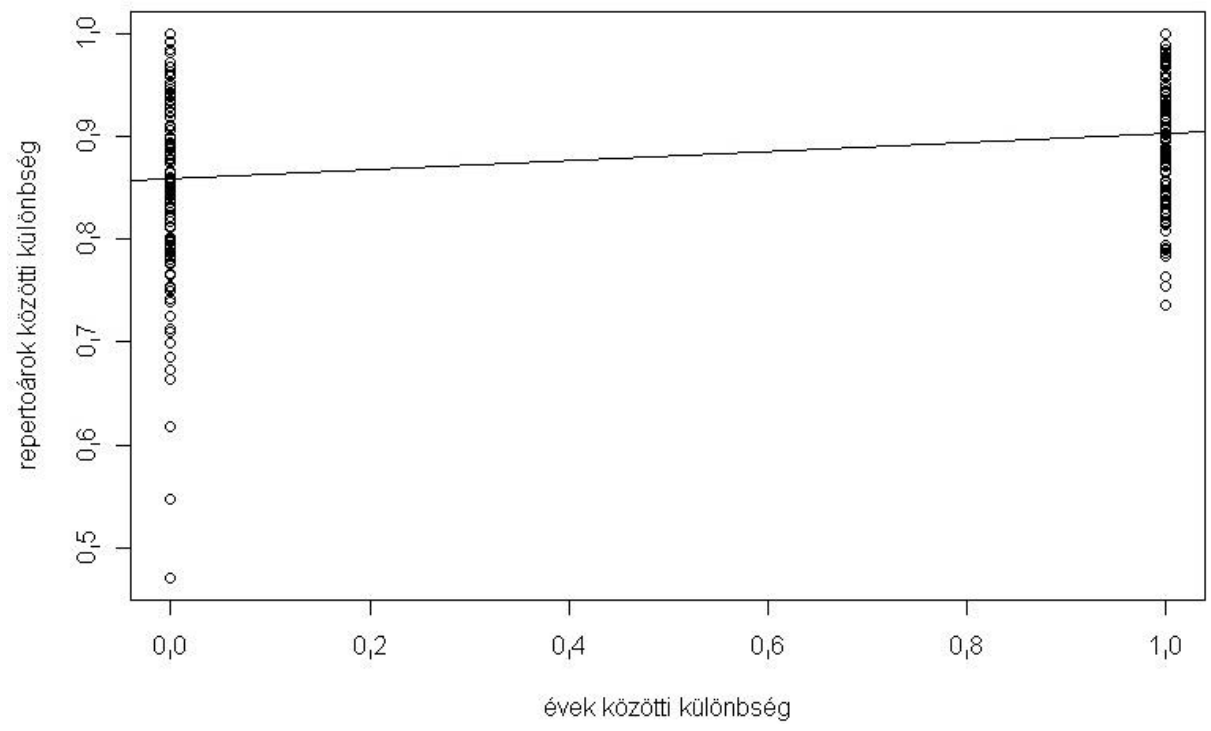

6. ábra. Diagramon ábrázolva a keleti szektor 2007-ben és 2008-ban éneklő hímjei

Figure 6. Biplot of the singing males of 2007 and 2008 in the eastern area

Az egyes években a koreloszlást a 2. táblázat mutatja.

Az ezekből az adatokból képzett kontingencia táblázatok azt mutatták, hogy a korstruktúra nem változik szignifikánsan az évek során (1. időmodell: $\chi^{2}=0,99, \mathrm{df}=2, \mathrm{p}=0,61$ és 2 . időmodell: $\varphi=-0,28, p=0,56)$. Így kizárhatjuk, hogy a kapott mintázat a változékony korstruktúra eredménye.

2. táblázat. Világosszürkével jelölve az első időmodell mintái, vagyis a 2005-ös, 2006-os és 2009-es években a nyugati szektorban éneklő hímek. Sötétszürkével jelölve a második időmodell mintái, ahol a 2007-es és 2008-as években a keleti szektorban éneklő hímeket vizsgáltuk.

Table 2. Age distribution of the time models' males. The first temporal model: 2005, 2006, 2009 western area is indicated by light grey. The second temporal model: 2007, 2008 eastern area is indicated by dark grey.

\begin{tabular}{|c|c|c|c|c|}
\hline év/hely & \multicolumn{2}{|c|}{ nyugati szektor } & \multicolumn{2}{c|}{ keleti szektor } \\
\hline & adult & juvenilis & adult & juvenilis \\
\hline $\mathbf{2 0 0 5}$ & 6 & 4 & & \\
\hline $\mathbf{2 0 0 6}$ & 11 & 7 & & \\
\hline $\mathbf{2 0 0 7}$ & & & 3 & 4 \\
\hline $\mathbf{2 0 0 8}$ & & & 1 & 5 \\
\hline $\mathbf{2 0 0 9}$ & 17 & 6 & & \\
\hline
\end{tabular}

\section{Térmodell}

A területhatást a 2007-es mintán vizsgáltuk, a keleti szektorban éneklő hímeknél (7. ábra). Bár a dendrogramon felfedezhető bizonyos mértékủ mintázat, a Mantel-teszt eredménye nem támasztja alá statisztikailag a terület és az ének kapcsolatát $(\mathrm{r}=-0,18, \mathrm{p}=0,95)$. 


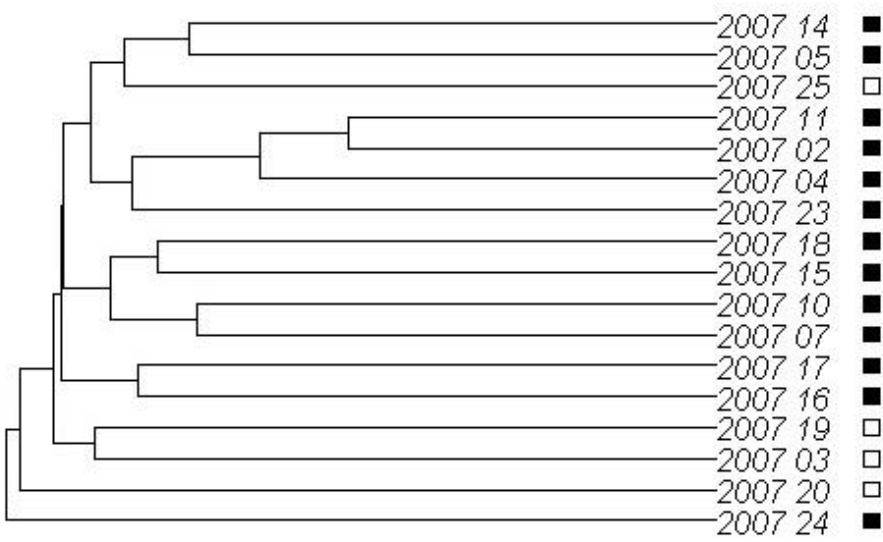

7. ábra. A térmodell dendrogramja (a 2007-es évben a két szektorban éneklö hímek).

Figure 7. Dendrogram of the spatial model (singing males of 2007 in the two areas).

\section{Értékelés}

Összefoglalásként elmondható, hogy a statisztikai eredmények részben igazolták az időbeli mintázatok meglétét az örvös légykapó énekben. Ahol a felbontás több évet fogott át, ott szignifikáns bizonyítékot találtunk arra, hogy az egymást követő években vizsgált egyedi repertoárok között nagyobb a hasonlóság, mint a hosszabb távú összehasonlításokban. A hosszú távú vizsgálat alapján tehát azt a következtetést lehet levonni, hogy az ének populációs szinten időben változik. Megjegyzendő, hogy amikor csak közvetlenül egymást követő éveket hasonlítottunk össze, akkor a két mintánk közül csak az egyikben mutatkozott szignifikáns különbség a két év egyedi repertoárjai között. Ez a mintázat azt mutathatja, hogy a változás ebben a rövidebb időintervallumban is létezhet, de mértéke nem feltétlenül akkora, hogy statisztikailag minden esetben igazolható legyen. Vagyis, ha ezek a korrelatív különbségek az egyedi és populációs szintủ repertoárok dinamikus változását tükrözik, akkor azt a következtetést vonhatjuk le, hogy a szillablakészlet az egymást követö években kisebb mértékben változik, mint hosszabb távon és a változások hosszabb távon értelemszerüen akkumulálódnak.

Miután az időbeli mintázatok megléte bizonyítást nyert, feltételezhetjük, hogy az örvös légykapó énekében egy emberi divathullámokhoz hasonló mechanizmus müködik, azaz egyes szillablák megjelennek, elterjednek, ritkulnak, majd eltủnnek az évek során. Egy ilyen lehetőség további biológiai kérdéseket vet fel. Például felmerül, hogy az egyes szillablák jelentéstartalma között különbség van, mert képzésüknek és repertoárban tartásuknak különböző költsége és haszna van (például vannak olyan szillablák amelyek vonzók a tojók számára vagy éppen ellenkezőleg hatnak), illetve, hogy az egyes szillablák haszná- 
latának milyen következményei vannak az egyedek közötti kommunikációban. A kanári (Serinus canaria) esetében már bebizonyították, hogy egyes szillablák (az ún. „szexi” szillablák) használata vonzó lehet a tojók számára (VALLET \& KREUTZER 1995, VALLET et al. 1998, GAHR et al. 2001). A légykapóénekben ilyen állandó szereppel bíró szillablák meglétét nem sikerült bizonyítani (GARAMSZEGI et al. 2012), de eredményeink alapján elképzelhető, hogy nem állandó, rögzült szillablákat kell keresni, hanem bizonyos időszakonként más-más szillablát vagy szillablakombinációt, amely aktuálisan vonzó a tojók számára. Egy későbbi időpillanatban (pár év múlva) viszont más szillabla vagy szillablakombináció terjed el. Ez a változó jelentéstartalom vezethet az időben megjelenő mintázatokhoz, amiket mi is találtunk.

Az évek során változó szillablakészlet (ill. az esetleges változó jelentéstartalom) kielégíti a gyakoriságfüggés alapján müködő szignálrendszerek modelljeinek predikcióit. (SINERVO \& LIVELY 1996). A foltos oldalú gyík (Uta stansburiana) esetében leírták, hogy a torokszínezet gyakoriságfüggő szelekciója egy, a kö-papír-olló játék dinamikájához hasonlítható mechanizmus alapján müködik (SINERVO \& LIVELY 1996). A foltos oldalú gyík hímek nyaka három színü lehet, sárga, narancs vagy kék, mely színeknek igen fontos szerepe van a territóriumokért folytatott versengés kimenetelében. A populáción belül a különböző színű alakok hatéves periódusban váltakozva terjednek el, attól függően, hogy éppen melyik szín gyakorisága a legalacsonyabb a populációban. Ha az örvös légykapónál is ehhez hasonló szelekció müködik, akkor a gyakoriságfüggés lehet a magyarázata annak, hogy bizonyos szillablák jelentéstartalma vagy a velük járó nyereség (például párosodási siker) az idő múltával változik, relatív gyakorisága ezért csökken. Ezzel párhuzamosan viszont a tojók számára az újonnan megjelenő és kezdetben ritka szillablák lesznek vonzóak (vagy hatékonyak a territóriumok foglalásánál). Mivel a rendelkezésre álló jelzéskészlet jóval több három elemnél, ha a gyakoriságfüggés érvényes, akkor az nem ciklikus, hanem lineárisan előremutató szelekciót eredményezhet a populáció szillablakészletén.

Korábban már több kutatás is kimutatta, hogy egyes énekesmadarak énekének esetében beszélhetünk dialektusról, vagyis megjelenik a területhatás (LEMON 1975, BAPTISTA 1977, HARBISON et al. 1999, MACDOUGALL-SHACKLETON \& MACDOUGALL-SHACKLETON 2001, Podos \& WARREN 2007, O'LOGHLEN et al. 2011, ThiELTGES et al. 2014). Továbbá bizonyítást nyert, hogy az örvös légykapó éneke is mutat bizonyos térhatást rövidebb időskálán vizsgálva, ugyanis a szomszédos territóriumokon éneklő hímek éneküket úgy változtatják, hogy a szillabla átfedés minél kisebb legyen, vagyis énekük különbözzön. Ez a folyamat egyfajta negatív tanulásnak tekinthető (GARAMSZEGI et al 2012). Esetünkben azonban területhatást nem sikerült igazolni. Ennek oka lehet az alacsony mintaszám, aminek következtében a területhatásra vonatkozó teszteket csak szükebb adatbázison tudtuk elvégezni. Megjegyzendő az is, hogy a területhatás esetében a Mantel-teszttel végzett vizsgálat nem vette figyelembe az egyes hímek valós térbeli távolságát, csak azt, hogy azonos vagy különbözö telepen énekeltek-e.

Eredményeinket abban az esetben lehet a kulturális evolúció eredményeként interpretálni, ha teljesül az a feltétel, hogy a kapott mintázatok az egyedek közötti tanulás következtében jönnek létre. Vizsgálatainkat erre a feltételezésre alapoztuk, mivel az ilyen komplex énekkel rendelkező énekesmadarak éneküket általában tanulják (CATCHPOLE \& SLATER 2008). Az örvös légykapóval szoros rokonságban álló kormos légykapónál már bebizonyí- 
tották, hogy a hím valóban tanulja énekét (ESPMARK \& LAMPE 1993). A genetikai öröklödés elemeit, azok hatásait azonban nem ismerjük, így kizárni sem tudjuk.

Vizsgálatunk nem terjed ki az örvös légykapóegyedek énekének időbeli változására, mert a vizsgált hat év során nem tudtuk elegendő hím énekét egymást követő több évben is rögzíteni. Egy párhuzamosan futó, több évet átölelő vizsgálat azt mutatja, hogy az egyes örvös légykapó hímek éneke változik évről évre, de úgy, hogy az ének mindvégig megtartja egyedspecifikusságát (ZSEBÖK et al. nem publikált adat). Ezek az eredmények azt mutatják, hogy az egyedi énekek valamennyire plasztikusak és a hímek képesek repertoárjukba újabb és újabb elemeket beépíteni, ahogy azt a szociális úton történő tanulás és a kulturális evolúció mechanizmusa feltételezi.

Vizsgálatainkba nem vettünk bele lehetséges egyéb változókat, melyek egy korrelatív vizsgálatban azonban fontosak lehetnek, egyedül a korstruktúra hatására kontroláltunk. Felmerült ugyanis az a lehetöség, hogy a kapott mintázatot a különböző korosztályú hímek eltérő aránya okozza. Bizonyított, hogy a légykapó hímek repertoármérete szoros összefüggésben van a korukkal (GARAMSZEGI et al. 2007) és előfordulhat, hogy a különböző szektorokban vagy években más-más korstruktúra alakult ki. Ez is eredményezhette volna, hogy térben és/vagy időben különböző repertoárbeli hasonlóságot tapasztaltunk, de ebben az esetben ezt a mintázatot nem tekinthettük volna a kulturális evolúció eredményének. Az ide vonatkozó statisztikai elemzések viszont azt mutatták, hogy a kapott időbeli mintázatokat valószínüleg nem befolyásolja a korstruktúra évenkénti változása.

Köszönetnyilvánítás. A szerzők köszönetüket fejezik ki az ELTE Állatrendszertani és Ökológiai Tanszékén müködő Viselkedésökológiai Csoport tagjainak, valamint a Pilisi Parkerdő Zrt.-nek. Kutatásaink anyagi hátterét a Nemzeti Kutatási, Fejlesztési és Innovációs Hivatal - NKFIH, K-105517, K115970 és PD-115730 pályázatai biztosították, valamint a spanyol Gazdasági és Versenyképességi Minisztérium CGL2015-70639-P számú pályázata. Köszönjük továbbá a két anonim bíráló rendkívül hasznos észrevételeit.

\section{Irodalomjegyzék}

BAKER, M. C., BAKER, M. S. A. \& BAKER, E. M. (2003): Rapid evolution of a novel song and an increase in repertoire size in an island population of an Australian songbird. Ibis 145: 465-471. https://doi.org/10.1046/j.1474-919X.2003.00190.x

BAPTISTA, L. F. (1977): Geographic variation in song and dialects of puget sound white-crowned sparrow. Condor 79: 356-370. https://doi.org/10.2307/1368014

BeEChER, M. D. \& Brenowitz, E. (2005): Functional aspects of song learning in songbirds. Trends in Ecology and Evolution 20: 143-149. https://doi.org/10.1016/j.tree.2005.01.004

Catchpole, C. K. \& Slater, P. J. B. (eds) (2008): Bird Song: Biological Themes and Variations. Cambridge University Press, Cambridge, $335 \mathrm{pp}$.

CoHEN, J. (1960): A coefficient of agreement for nominal scales. Educational and Psychological Measurement 20: 37-46. https://doi.org/10.1177/001316446002000104 
DANChIN, É. \& WAGNER, R. H. (2010): Inclusive heritability: combining genetic and non-genetic information to study animal behavior and culture. Oikos 119: 210-218. https://doi.org/10.1111/j.1600-0706.2009.17640.x

Eriksen, A., Slagsvold, T. \& LAmPe, H. M. (2011): Vocal Plasticity - are Pied Flycatchers, Ficedula Hypoleuca, Open-Ended Learners? Ethology 117: 188-198. https://doi.org/10.1111/j.14390310.2010.01864.X

EsPMARK, Y. O. \& LAMPE, H. M. (1993): Variations in the song of the pied flycatcher within and between breeding seasons. Bioacoustics 5: 33-65. https://doi.org/10.1080/09524622.1993.9753229

Gahr, M., Voigt, C. \& Leitner, S. (2001): Seasonal Changes in the Song Pattern of the NonDomesticated Island Canary (Serinus canaria) a Field Study. Behaviour 138: 885-904. https://doi.org/10.1163/156853901753172700

GALEF, B. G. \& LALAND, K. N. (2005): Social learning in animals: Empirical studies and theoretical models. Bioscience 55: 489-499. https://doi.org/10.1641/0006-3568(2005)055[0489:SLIAES]2.0.CO;2

GARAMSZEGI, L. Z. (2002): The estimation of size and change in composition of avian song repertoires. Animal Behaviour 63: 623-630. https://doi.org/10.1006/anbe.2001.1906

GARAMSZEGI, L. Z. (2004): Immune challenge mediates vocal communication in a passerine bird: an experiment. Behavioral Ecology 15: 148-157. https://doi.org/10.1093/beheco/arg108

Garamszegi, L. Z., Merino, S., TÖröK, J., Eens, M. \& Martínez, J. (2006): Indicators of physiological stress and the elaboration of sexual traits in the collared flycatcher. Behavioral Ecology 17: 399-404. https://doi.org/10.1093/beheco/arj042

Garamszegi, L. Z., TöröK, J., Hegyi, G., Szöllõsi, E., Rosivall, B. \& Eens, M. (2007): Agedependent expression of song in the collared flycatcher, Ficedula albicollis. Ethology 113: 246256. https://doi.org/10.1111/j.1439-0310.2007.01337.x

GARAMSZEGI, L. Z., ZSEBÖK, S. \& TÖRÖK, J. (2012): The relationship between syllable repertoire similarity and pairing success in a passerine bird species with complex song. Journal of Theoretical Biology 295: 68-76. https://doi.org/10.1016/j.jtbi.2011.11.011

GELTER, H. P. (1987): Song differences between the pied flycatcher Ficedula hypoleuca, the collared flycatcher Ficedula albicollis, and their hybrids. Ornis Scandinavica 18: 205-215. https://doi.org/10.2307/3676768

Harbison, H., Nelson, D. A. \& HAhn, T. P. (1999): Long-term persistence of song dialects in the mountain white-crowned sparrow. Condor 101: 133-148. https://doi.org/10.2307/1370454

Hegyi, G., Herényi, M., Wilson, A. J., Garamszegi, L. Z., Rosivall, B., Eens, M. \& TöröK, J. (2010): Breeding experience and the heritability of female mate choice in collared flycatchers. PLoS One 5: e13855. https://doi.org/10.1371/journal.pone.0013855

LAhti, D. C., Moseley, D. L. \& Podos, J. (2011): A tradeoff between performance and accuracy in bird song learning. Ethology 117: 802-811. https://doi.org/10.1111/j.1439-0310.2011.01930.x

LANDIS, J. R. \& KocH, G. G. (1977): The measurement of observer agreement for categorical data. Biometrics 33: 159-174. https://doi.org/10.2307/2529310

LEMON, R. E. (1975): How birds develop song dialects. Condor 77: 385-406. https://doi.org/10.2307/1366087

LUTHER, D. \& BAPTISTA, L. (2010): Urban noise and the cultural evolution of bird songs. Proceedings of the Royal Society of London B 277: 469-473. https://doi.org/10.1098/rspb.2009.1571 
MacDougall-Shackleton, E. A. \& MacDougall-Shackleton, S. A. (2001): Cultural and genetic evolution in mountain white-crowned sparrows: song dialects are associated with population structure. Evolution 55: 2568-2575. https://doi.org/10.1111/j.0014-3820.2001.tb00769.x

MANTEL, N. (1967): Ranking procedures for arbitrarily restricted observation. Biometrics 23: 65-78. https://doi.org/10.2307/2528282

MARLER, P. \& TAMURA, M. (1959): Song "dialects" in three populations of white-crowned sparrows. Condor 368: 368-377.

MARLER, P. \& TAMURA, M. (1964): Culturally transmitted patterns of vocal behavior in sparrows. Science 146: 1483-1486. https://doi.org/10.1126/science.146.3650.1483

NELSON, D. (2000): Song overproduction, selective attrition and song dialects in the white-crowned sparrow. Animal Behaviour 60: 887-898. https://doi.org/10.1006/anbe.2000.1560

Oksanen, J., Blanchet, F. G., Kindt, R., Legendre, P., Minchin, P. R., O'Hara, R., B., Simpson, G. L., Solymos, P., Stevens, M. H. H. \& Wagner, H. (2016): vegan: Community Ecology Package. $\mathrm{R}$ package version 2.3-3.

O’Loghlen, A. L., Ellis, V., Zaratzian, D. R., Merrill, L. \& Rothstein, S. I. (2011): Cultural evolution and long-term song stability in a dialect population of brown-headed cowbirds. Condor 113: 449-461. https://doi.org/10.1525/cond.2011.100103

Paradis, E., Claude, J. \& StRIMmER, K. (2004): APE: analyses of phylogenetics and evolution in R language. Bioinformatics 20: 289-290. https://doi.org/10.1093/bioinformatics/btg412

PodANI, J. (1997): Bevezetés a többváltozós biológiai adatfeltárás rejtelmeibe. Scientia Kiadó, Budapest, $412 \mathrm{pp}$

Podos, J., Huber, S. K. \& TAFT, B. (2004): Bird song: The inferface of evolution and mechanism. Annual Review of Ecology, Evolution and Systematics 35: 55-87. https://doi.org/10.1146/annurev.ecolsys.35.021103.105719

PoDOS, J. \& WARREN, P. S. (2007): The evolution of geographic variation in birdsong. Advences in the Study of Behaviour 37: 403-458. https://doi.org/10.1016/S0065-3454(07)37009-5

R Core Team (2015). R: A language and environment for statistical computing. R Foundation for Statistical Computing, Vienna, Austria. URL https://www.R-project.org/.

SARKAR, D. (2008): Lattice: Multivariate Data Visualization with R. Springer, New York. https://doi.org/10.1007/978-0-387-75969-2

van SCHAiK, C. P. (2010): Social Learning and Culture in Animals. In: KAPPELER, P. (ed.) Animal Behaviour: Evolution and Mechanisms: University of Göttingen, Göttingen, pp. 623-653. https://doi.org/10.1007/978-3-642-02624-9_20

SCHLIEO, K. P. (2011): phangorn: phylogenetic analysis in R. Bioinformatics, 27: 592-593. https://doi.org/10.1093/bioinformatics/btq706

SimpSON, G. L. (2016): Permute: Functions for Generating Restricted Permutations of Data., package version 0.9-9

Sinervo, B. \& Lively, C. M. (1996): The rock-paper-scissors game and the evolution of alternative male strategies. Nature 380: 240-243. https://doi.org/10.1038/380240a0

SLATER, P. J. B. (1986): The cultural transmission of bird song. Trends in Ecology \& Evolution 1: 94 97. https://doi.org/10.1016/0169-5347(86)90032-7

SoKal, R. R. \& RoHLF, F. J. (1995): Biometry. W. H. Freeman, 887 pp.

Thieltges, H., Henry, L., Biquand, V. \& Deleporte, P. (2014): Short-term variations of dialects in short songs of two species of colonial caciques (Cacicus). Acta Acustica united with Acustica 100: 759-766. https://doi.org/10.3813/AAA.918755 
VASKUTI É. et al.

VAllet, E., Beme, I. \& Kreutzer, M. (1998): Two-note syllables in canary songs elicit high levels of sexual display. Animal Behaviour 55: 291-7. https://doi.org/10.1006/anbe.1997.0631

VALLET, E. \& KREUTZER, M. (1995): Female canaries are sexually responsive to special song phrases. Animal Behaviour 49: 1603-1610. https://doi.org/10.1016/0003-3472(95)90082-9

WALLIN, L. (1987): Integration of a call into the song of the collared flycatcher - adaptive compenstion for broadcast efficency. Ornis Scandinavica 18: 42-46. 


\title{
Cultural evolution in the song of the collared flycatcher (Ficedula albicollis)
}

\author{
ÉVA VASKUTI ${ }^{1 *}$, SÁNDOR ZSEBöK ${ }^{1}$, GÁBOR HERCZEG ${ }^{1}$, GYÖRGY BLÁZI $^{1}$, \\ MIKLÓS LACZI ${ }^{1}$, GERGELY NAGY $^{1}$, JÁNOS TÖRÖK $^{1} \&$ LÁSZLÓ ZSOLT GARAMSZEGI ${ }^{2}$
}

${ }^{1}$ Behavioural Ecology Group, Eötvös Loránd University, Department of Systematic Zoology and Ecology, Pázmány Péter sétány 1/C, H-1117 Budapest, Hungary.*E-mail: vaskuti.eva@ gmail.com

${ }^{2}$ Estación Biológica de Doñana-CSIC, c/ Américo Vespucio s/n, 41092 Sevilla, Spain

\section{ÁLLATTANI KÖZLEMÉNYEK (2016) 101(1-2): 25-41.}

\begin{abstract}
The process of cultural evolution - which is based on social learning through information transferred between individuals or generations instead of genetic inheritance - is one of the main factors that determined human evolution. However cultural evolution is not only an idiosyncrasy of human beings, but it also has a great importance in animals. One of the basic requirements of cultural evolution is that individuals copy behavioral traits from each other, which is well-studied in bird song. When such copying occurs among individual songbirds, the elements of their song, so called syllables, will not be randomly distributed, but structured in time and space. To test this hypothesis, we analyzed 1740 songs of 103 collared flycatcher (Ficedula albicollis) males from a population of the Pilis Mountains (Hungary), where songs were recorded between 2005 and 2010. We defined 476 syllable types within the population. To examine if the similarity in males' song follows a temporal or spatial structure, we calculated similarity matrices based on the overlap of syllable use and compared them by using Mantel-test. We found that the composition of the population's song is organized in time: certain syllables become temporally spread than turn rare over the years. Furthermore, the song of those males who sing closer in time to each other shows greater similarity than of those who sing at higher temporal distance. The detected temporal patterns depended on the considered scale, as the differences between non-consecutive years were more emphasized than between consecutive years. We could not prove the existence of the spatial structure in the song data, probably due to the limitations of available data. In summary, our results could partially support the hypothesis that cultural evolution can appear in the song of the collared flycatcher.
\end{abstract}

Keywords: social learning, syllable, temporal and spatial patterns, Mantel-test, dendrogram. 